\title{
Guide to further reading
}

\section{Websites}

Since the first edition of this book appeared, some extremely useful websites have been developed. All are subscription-free and offer original materials, including case Opinions, oral arguments and amicus briefs, as well as commentary and analysis.

The Oyez Project: www.oyez.org This is a wonderful resource. As well as accessible summaries of all cases, there are also oral arguments, weekly round-ups and short pieces of analysis.

Supreme Court of the United States: www.supremecourt.gov This is the official website of the United States Supreme Court and contains case Opinions, biographies of the Justices and many other details about the Court's history and operation.

SCOTUSblog: www.scotusblog.com As you would expect, this contains commentaries on cases and on the Court's behaviour, but there are also video presentations of scholars' analyses and a useful glossary of terms.

The Supreme Court Database: http://supremecourtdatabase.org A scholarly website with a mass of detail on every case.

For a more partisan take on Supreme Court cases, many interest groups and think tanks offer information and commentary on the Court's decisions. On the conservative side there are, for example, The Federalist Society (www.fed-soc.org) and the Ethics and Public Policy Center (http://eppc. org). On the liberal side there are, for example, the American Civil Liberties Union (www.aclu.org) and Alliance for Justice (www.afj.org).

\section{General reference}

General books on the Supreme Court fall into three main categories: student textbooks, advanced scholarly analyses and contemporary histories, often written by journalists. The first category includes: 
David M. O'Brien, Storm Center: The Supreme Court in American Politics, 9th edn, Norton: New York, 2011.

Richard L. Pacelle, The Supreme Court in a Separation of Powers System: The Nation's Balance Wheel, Routledge: London, 2015.

The second category includes:

Erwin Chermerinsky, The Case against the Supreme Court, Viking: New York, 2014. Cornell Clayton and Howard Gillman, The Supreme Court in American Politics: New Institutionalist Interpretations, University Press of Kansas: Lawrence, 1999.

Laurence Tribe and Joshua Matz, Uncertain Justice: The Roberts Court and the Constitution, Henry Holt: New York, 2014.

The third category includes:

Marcia Coyle, The Roberts Court: The Struggle for the Constitution, Simon \& Schuster: New York, 2014.

Jeffrey Toobin, The Oath: The Obama White House and the Supreme Court, Random House: New York, 2013.

Another valuable reference text with a focus on the clauses of the Constitution and their basic interpretation by the Court is:

Sue Davis, Corwin and Peltason's Understanding the Constitution, 17th edn, Thomson Wadsworth: Belmont, CA, 2007.

\section{Chapter 1 - The Court's contemporary agenda}

The most detailed work on the process of agenda building on the Court is:

H.W. Perry, Deciding to Decide: Agenda Setting in the United States Supreme Court, Harvard University Press: Cambridge, MA, 1991.

Books that bring out the connections between the legal and political contexts of the Court's modern agenda include:

Lee Epstein and Joseph Kobylka, The Supreme Court and Legal Change: Abortion and the Death Penalty, University of North Carolina Press: Chapel Hill, 1992.

Robert McKeever, Raw Judicial Power? The Supreme Court and American Society, 2nd edn, Manchester University Press: Manchester, 1995.

Richard Pacelle, The Transformation of the Supreme Court's Agenda: From the New Deal to the Reagan Administration, Westview Press: Boulder, CO, 1991.

Books that summarise in an accessible fashion a broad range of cases dealt with by the Court include:

Henry Abraham and Barbara Perry, Freedom and the Court: Civil Rights and Liberties in the United States, 8th edn, University Press of Kansas: Lawrence, 2003.

Lucius J. Barker, Michael Combs, Kevin Lyles, H.W. Perry, Jr and Twiley Barker, Civil Liberties and the Constitution: Cases and Commentaries, 9th edn, Prentice-Hall: Upper Saddle River, NJ, 2010. 
Books dealing with specific issues include:

Ronald Collins and David Skover, When Money Speaks: The McCutcheon Decision, Campaign Finance Laws, and the First Amendment, Top Five Books: Oak Park, IL, 2014.

Clare Cushman, Supreme Court Decisions and Women's Rights, 2nd edn, CQ Press: Washington, DC, 2010.

Jeffrey L. Kirchmeier, Imprisoned by the Past: Warren McCleskey and the American Death Penalty, Oxford University Press: New York, 2014.

Michael J. Klarman, From Jim Crow to Civil Rights: The Supreme Court and the Struggle for Racial Equality, Oxford University Press: New York, 2006.

Dorothy E. McBride, Abortion in the United States: A Reference Handbook, ABC-CLIO: Santa Barbara, CA, 2008.

Michael J. Perry, Constitutional Rights, Moral Controversy and the Supreme Court, Cambridge University Press: Cambridge, 2010.

Jason Pierceson, Same-sex Marriage in the United States: The Road to the Supreme Court, Rowman \& Littlefield: Lanham, MD, 2013.

\section{Chapter 2 - A historical overview}

The best general histories of the Supreme Court are:

Peter Irons, A People's History of the Supreme Court, rev. edn, Penguin: New York, 2005.

Bernard Schwartz, A History of the Supreme Court, Oxford University Press: New York, 1995.

A more interpretive and selective history with a focus on the 'great' Justices and other judges is:

G. Edward White, The American Judicial Tradition, 3rd edn, Oxford University Press: Oxford, 2007.

Histories of particular periods in the Court's history include:

Vincent Blasi (ed.), The Burger Court: The Counter-Revolution That Wasn't, Yale University Press: New Haven, CT, 1983.

Archibald Cox, The Warren Court: Constitutional Decision as an Instrument of Reform, Oxford University Press: Oxford, 1968.

David Savage, Turning Right: The Making of the Rehnquist Court, Wiley: New York, 1993.

James Simon, The Centre Holds: The Power Struggle Inside the Rehnquist Court, Simon \& Schuster: New York, 1999.

Mark Tushnet, In the Balance: Law and Politics on the Roberts Court, Norton: New York, 2013.

Bob Woodward and Scott Armstrong, The Brethren: Inside the Supreme Court, Simon \& Schuster: New York, 1979. 


\section{Chapter 3 - Cases, decisions and judicial procedures}

Among the books recounting the history of particular cases are:

Bruce Ackerman (ed.), Bush v. Gore: The Question of Legitimacy, Yale University Press: New Haven, CT, 2002.

Joel Dreyfuss and Charles Lawrence, The Bakke Case: The Politics of Inequality, Harcourt Brace Jovanovich: New York, 1979.

Marian Faux, Roe v. Wade, Cooper Square Press: New York, 2001.

Richard Kluger, Simple Justice: The History of Brown v. Board of Education, Knopf Doubleday: New York, 2011.

Anthony Lewis, Gideon's Trumpet, Random House: New York, 1964.

Nathaniel Persily, Gillian E. Metzger and Trevor W. Morrison (eds), The Health Care Case: The Supreme Court's Decision and Its Implications, Oxford University Press: New York, 2013.

Ian Shapiro, Abortion: The Supreme Court Decisions, 1965-2000, Hackett: Indianapolis, 2001.

Dealing with the basic details of legal procedures are:

H.W. Perry, Deciding to Decide: Agenda Setting in the United States Supreme Court, Harvard University Press: Cambridge, MA, 1991.

Bernard Schwartz, Decision: How the Supreme Court Decides Cases, Oxford University Press: Oxford, 1996.

\section{Chapter 4 - Politics and judicial review}

Many of the works offering either interpretivist or non-interpretivist theories of judicial review are quite challenging for those new to the study of the Supreme Court. Those listed below, therefore, have been selected for their accessibility as well as their importance. For works dealing with extrajudicial influences on the Court, see also the listing for Chapter 6 .

Robert Bork, The Tempting of America: The Political Seduction of the Law, Touchstone: New York, 1990.

Jesse Choper, Judicial Review and the National Political Process, Quid Pro Books: New Orleans, 2013.

John Hart Ely, Democracy and Distrust: A Theory of Judicial Review, Harvard University Press: Cambridge, MA, 1980.

David O'Brien (ed.), Judges on Judging: Views from the Bench, 4th edn, Sage: London, 2013.

Jack Rakove (ed.), Interpreting the Constitution: The Debate over Original Intent, Northeastern University Press: Boston, 1990.

Bernard Schwartz, The New Right and the Constitution: Turning Back the Legal Clock, Northeastern University Press: Boston, 1990.

Christopher Wolfe, The Rise of Modern Judicial Review: From Constitutional Interpretation to Judge-Made Law, Rowman \& Littlefield: Lanham, MD, 1994. 


\section{Chapter 5 - Supreme Court appointments}

Henry Abraham, Justices and Presidents, 5th edn, Rowman \& Littlefield: Lanham, MD, 2008.

D. Brock, The Real Anita Hill: The Untold Story, The Free Press: New York, 1993.

Ethan Bronner, Battle for Justice: How the Bork Nomination Shook America, Norton: New York, 1989.

Stephen Carter, The Confirmation Mess: Cleaning up the Federal Appointments Process, Basic Books: New York, 1994.

Christopher Eisgruber, The Next Justice: Repairing the Supreme Court Appointments Process, Princeton University Press: Princeton, NJ, 2009.

Lee Epstein and Jeffrey Segal, Advice and Consent: The Politics of Judicial Appointments, Oxford University Press: New York, 2005.

Jane Mayer and Jill Abramson, Strange Justice: The Selling of Clarence Thomas, Plume: New York, 1995.

Michael Pertschuk and Wendy Schaetzel, The People Rising: The Campaign against the Bork Nomination, Thunder's Month Press: New York, 1989.

Herman Schwartz, Packing the Courts: The Conservative Campaign to Rewrite the Constitution, Charles Scribner's Sons: New York, 1988.

James Simon, In His Own Image: The Supreme Court in Richard Nixon's America, McKay: New York, 1973.

Laurence Tribe, God Save This Honorable Court: How the Choice of Supreme Court Justices Shapes Our History, Random House: New York, 1985.

Elder Witt, A Different Justice: Reagan and the Supreme Court, CQ Press: Washington, DC, 1986.

\section{Chapter 6 - The power of the Supreme Court}

Theodore Becker and Malcolm Feeley, The Impact of Supreme Court Decisions, 2nd edn, Oxford University Press: New York, 1973.

Alexander Bickel, The Least Dangerous Branch, Bobbs Merrill: Indianapolis, 1962.

Bradley Canon and Charles Johnson, Judicial Policies: Implementation and Impact, CQ Press: Washington, DC, 1999.

Lincoln Caplan, The Tenth Justice, Vintage: New York, 1987.

Cornell Clayton, The Politics of Justice: The Attorney General and the Making of Government Legal Policy, Routledge: New York, 2015.

Paul M. Collins, Friends of the Supreme Court: Interest Groups and Judicial Decision Making, Oxford University Press: New York, 2008.

Richard Davis, Decisions and Images: The Supreme Court and the Press, Prentice Hall: Upper Saddle River, NJ, 1994.

Louis Fisher, Constitutional Dialogues: Interpretation as Political Process, Princeton University Press: Princeton, NJ, 1988.

Charles Fried, Law and Order: Arguing the Reagan Revolution - A Firsthand Account, Simon \& Schuster: New York, 1991.

Edward Keynes with Randal Miller, The Court vs. Congress: Prayer, Busing and Abortion, Duke University Press: Durham, NC, 1989. 
Thomas R. Marshall, Public Opinion and the Rehnquist Court, State University of New York Press: Albany, 2008.

Walter Murphy, Elements of Judicial Strategy, University of Chicago Press: Chicago, 1964.

Gerald Rosenberg, The Hollow Hope: Can Courts Bring about Social Change?, 2nd edn, University of Chicago Press: Chicago, 2008.

Melvin Urofsky, Supreme Decisions: Great Constitutional Cases and Their Impact, Basic Books: New York, 2012.

\section{Chapter 7 - The role of the Supreme Court in American government and politics}

Many of the works listed above, especially in relation to Chapters 4 and 6, are useful on this subject. But see also:

Archibald Cox, The Role of the Supreme Court in American Government, Oxford University Press: Oxford, 1976.

Robert Dahl, 'Decision-Making in a Democracy: The Supreme Court as a National Policy-Maker', Journal of Public Law, VI, 1957, pp. 279-95; reprinted in Martin Shapiro, The Supreme Court and Public Policy, Scott, Foresman: Glenview, IL, 1969, pp. 57-64.

Ward Elliott, The Rise of Guardian Democracy, Harvard University Press: Cambridge, MA, 1974.

Nathan Glazer, 'Toward an Imperial Judiciary', The Public Interest, XLI, 1975, pp. 104-23.

Arthur Miller, The Supreme Court and American Capitalism, The Free Press: New York, 1968.

Terri Jennings Peretti, In Defense of a Political Court, Princeton University Press: Princeton, NJ, 1999. 